\title{
Textiles: Decay and Preservation in Seventeenth- to Nineteenth-Century Burials in Finland
}

\author{
Sanna Lipkin $(\mathbb{D} \cdot$ Erika Ruhl • Krista Vajanto • \\ Annemari Tranberg • Jenni Suomela
}

Accepted: 10 July 2019 /Published online: 30 November 2020

(C) The Author(s) 2020

\begin{abstract}
The taphonomy of human remains and associated funerary textiles are inevitably linked. The interplay among burial clothes, human remains, insects, rodents, and preservation is explored through study of a group of postmedieval burials in Finland. These burials have been either archaeologically excavated or inventoried beneath wooden church floors. Decay and preserving factors for various conditions are studied, allowing in-depth study of individual garments and identification of the burial season. In addition, research has revealed different factors that have an effect on future preservation of the burials under church floors.
\end{abstract}

Extracto La tafonomía de los restos humanos y los tejidos funerarios asociados están inevitablemente vinculados. La interacción entre la ropa funeraria,

\section{S. Lipkin $(\bowtie) \cdot$ A. Tranberg \\ Department of Archaeology, University of Oulu, Pentti Kaiteran katu 1, Linnanmaa, PL 8000, FI-90014 Oulu, Finland e-mail: sanna.lipkin@oulu.fi \\ E. Ruhl \\ SUNY at Buffalo, 380 Fillmore Academic Center, Ellicott Complex, Buffalo, NY 14261, U.S.A.}

\section{K. Vajanto}

Nanomicroscopy Center, Aalto University, Puumiehenkuja 2 (door H), FI-02150 Espoo, Finland

\section{J. Suomela}

Department of Education/Craft Studies, University of Helsinki, PO Box 8 (Siltavuorenpenger 10), FI00014 Helsinki, Finland los restos humanos, los insectos, los roedores y la conservación se explora mediante el estudio de un grupo de entierros posmedievales en Finlandia. Estos entierros han sido excavados arqueológicamente $\mathrm{o}$ inventariados debajo de los pisos de madera de las iglesias. Se estudian los factores de descomposición y conservación para diversas condiciones, lo que permite un estudio en profundidad de las prendas individuales y la identificación de la temporada de entierro. Además, la investigación ha revelado diferentes factores que tienen un efecto en la conservación futura de los entierros debajo de los pisos de las iglesias.

Résumé La taphonomie des restes humains et les textiles funéraires associés sont inévitablement liés. L'interaction entre les vêtements du mort, les restes humains, les insectes, les rongeurs et la préservation est explorée dans le cadre de l'étude d'un groupe de tombes post-médiévales en Finlande. Ces tombes ont fait l'objet d'un inventaire ou de fouilles archéologiques sous les parquets de bois des églises. La décomposition et les facteurs de préservation pour différentes conditions sont étudiés, permettant une étude approfondie des vêtements individuels et une identification de la saison de l'enterrement. De plus, la recherche a mis en évidence différents facteurs ayant un effet sur la préservation future des tombes sous les sols des églises.

Keywords textiles - burial clothes $\cdot$ preservation . mummies $\cdot$ under-floor church burials $\cdot$ Finland 


\section{Introduction}

Although archaeological textiles can be preserved in a variety of conditions, they generally remain rare in many archaeological contexts. As such, excavators, with little actual data, are often left to conjecture what may have been present. Textile preservation often occurs in extreme environmental conditions. While dry, permafrost, and waterlogged environments are the most suitable conditions for textile preservation, textile fragments can also survive when in direct contact with metal objects or carbonized in burnt layers. This article examines the preservation of 17 th- to mid-19th-century funerary textiles from cemeteries and church sites in northern and southwestern Finland. These materials have preserved and decomposed in various circumstances that allow for a wide-ranging examination of the survival of contemporaneous textiles. While documenting and studying funerary attire to better understand the wide variety of social and cultural aspects of postmedieval burial rituals, we have paid particular attention to items' varying states of preservation. We have realized that various factors adversely impact preservation, and that preservation is the result of complex causal sequences that are often difficult to detect.

Recognition of the state of preservation of archaeological textiles is crucial in order to facilitate the interpretation of burial contexts and the identities of buried individuals. Finnish postmedieval funerary textiles have preserved in a variety of conditions. Many textiles found in church underfloor contexts are perfectly preserved on either mummified or skeletonized human remains, but our research has indicated that their future preservation may be endangered. Recording the taphonomic processes within the burials is also important in terms of garment identification and identification of the burial season. In burials, a single garment is usually preserved in fragments that may represent different states of preservation and thus prevent correct identification. In addition, analysis of the combined information from textile preservation, mummification, decomposition, and insect remains has enabled further research of burial customs (Lipkin, Niinimäki et al., this issue) and the seasonal effects of funerary activities (Kallio-Seppä and Tranberg, this issue).

\section{Excavated Textiles}

In Finland, postmedieval funerary textiles have been explored under two key circumstances, those excavated and those inventoried. Excavated textiles include those unearthed during excavations conducted within the old churchyard of Oulu Cathedral (excavations 1996 and 2002), at the site of Hailuoto church, which burned in 1968 (excavations 1985-1987), inside Köyliö church (excavations 2015), and textiles currently stored in the Pohjois-Pohjanmaan museo (Northern Ostrobothnia Museum), which records indicate were excavated in 1952 from a mass grave for soldiers of the Finnish War (1808-1809) as the result of construction work. The Koskela mass-grave textile material constitutes ca. 20 different fabrics (mostly wool) disintegrated into numerous pieces (Lipkin 2018).

At Oulu Cathedral a total of 266 burials have been excavated, of which 76 burials included textile remains (Kehusmaa 1997; Sarkkinen and Kehusmaa 2002). These are fragmentarily preserved, and the most prevalent materials are wool, silk, or combinations of these with metal thread. Most of the burials studied at Oulu Cathedral were never located below the church floor, despite a shift in the building's foundational footprint in the 18th century. These remains do not indicate any signs of mummification, but, nevertheless, the number of textiles is significant (ca. 200 textile fragments in 76 burials) (Kehusmaa 1997; Sarkkinen and Kehusmaa 2002). As the orientation of the church changed, parts of the old churchyard ended up beneath the new building. Approximately 130 of the churchyard burials from the time before the new cathedral (ca. 1600-1770s) were excavated inside it in 1996. Oulu Cathedral is a 1,540seat, neoclassical stone church that protected these burials from rainwater and frost for more than 200 years, although they remain subject to changes in soil moisture. However, there is no significant difference between the preservation of textiles from these burials and those burials that remained outside the church (excavated in 2002).

Oulu Cathedral is substantially larger than the churches in Hailuoto, Haukipudas, Keminmaa, Kempele, and Köyliö. In these churches, burials were placed beneath the wooden floors. In Hailuoto, a fire destroyed the wooden church in 1968, but it does not appear to have directly affected the burials, which had been covered with sand in 1756 (Paavola 1998:69); as a result, nothing within the burials was carbonized or 
melted. However, it is likely that the heat of the flames and water used to extinguish the fire impacted overall preservation. The bones from these burials are described as being similar to paste and were poorly preserved. At Hailuoto, silk and wool are also the most commonly preserved materials, and fragments of textiles have preserved in 24 out of 87 burials (Paavola 1998).

Köyliö church is in southwestern Finland, where winters are generally not as cold and long as they are in northern Finland. Six burials were excavated at Köyliö, all including textiles made of silk, wool, and bast fibers. The coffins found below the floors of this wooden church had, over the years, been partially buried in sand, but in most of the excavated burials the upper parts of the remains were not in direct contact with sand (Helamaa et al. 2016). All human remains were fully skeletonized, and bast-fiber (flax or nettle) textiles were highly decayed and dry, whereas wool and silk were considerably better preserved. At Köyliö a total of 69 different fabrics (in hundreds of fragments) were identified in six burials.

\section{Inventoried Textiles}

Inventoried textiles have been found in burials beneath the wooden floors of St. Michael's Church at Keminmaa and the Haukipudas and Kempele churches (inventoried in 1996, 2014-2017). These remain in situ under floors and lie atop — but have never been covered with - the local sandy soil; 60 burials at Keminmaa, 18 burials at Haukipudas, and 14 burials at Kempele have been inventoried (for a total of 92) (Alakärppä 1997; Alakärppä and Paavola 1997; Ojanlatva and Paavola 1997). The Haukipudas and Kempele churches are made of wood, while St. Michael's in Keminmaa is built of stone. Despite this difference in construction materials and the corresponding variation in humidity, recorded with meters placed under floors, there seem to be no clear differences in the mummification processes among these three churches. Of the 55 human remains from church under-floor contexts examined in this study, 30 were skeletonized (10 adults, 20 children) and 25 mummified to some level ( 8 adults, 17 children). Kempele church seems to be the lone church with mummified individuals only, while in the other churches some of the human remains have skeletonized.

The number of children is higher because of high child mortality, but, between children and adults, there does not seem to be a significant difference in the numbers of skeletonized or mummified human remains. Slightly mummified human remains are considered to be those that have mostly skeletonized, but have some remains of dry skin on the face or other parts of the body. Mummified human remains are more or less completely covered with skin and may have surviving organs or other soft tissues. These classifications have been recorded onsite or based on photographs, and, when available, computed-tomography (CT) scans. Of materials under church floors, well-preserved textiles are still almost intact. These textiles still hold their original form, and more than $50 \%$ of the textiles in each burial are estimated to have been preserved. On the microscopic fiber level, these textiles may show degradation, which makes some textiles fragile and subject to damage if moved. Mostly decayed textiles constitute small textile fragments in the burials, but at the same time they may be well preserved on a fiber level.

To explore the crucial differences in preservation between burials beneath churches and those in churchyards, where the effect of soil is greater, the textiles in question have undergone basic textile-structure documentation, which has recorded their type (weave pattern, quality, number of threads per $\mathrm{cm}$, thickness of threads, and sewing techniques), find context, purpose, and state of preservation. This has been done at both the macro- and microlevels, including photographic documentation utilizing a microlens and stereomicroscope. Additionally, several fiber samples have been studied using transmitted-light microscopy, polarized-light microscopy, and fiber cross sections, as well as scanning electron microscopy (SEM) and scanning electron microscopy with energy dispersive $\mathrm{x}$-ray spectroscopy (SEMedx). These methods have been used to identify and differentiate various bast fibers, to evaluate qualities of wool, and to identify dye mordants. Few samples have been analyzed for dyestuffs with ultra-highperformance liquid chromatography (UHPLC) dye analysis.

In addition to textiles, we have also paid attention to bedding materials, and all postdepositional processes, including insect and rodent activities, were recorded. Insect and plant remains from the burials have been collected, the organic matter was examined under a stereomicroscope, and macrofossils were identified using insect and seed reference collections kept by Oulu University's Department of Biology. Certain insect species and their life phases demand a specific habitat, 
which illuminates past circumstances and the mummification process.

\section{Dressing the Dead}

The type of burial clothing worn by the deceased impacts not only the available textile material, but also the preservation of human remains (Bouquin et al. 2013). A clearer understanding of dress contributes to analysis of the Finnish materials and further informs wider archaeological research, as the preservation of these burials and their associated attire is far superior to that of most archaeological contexts. Forensic experiments have widely addressed the impact of external factors - climate, burial style, and temperature, to name a fewand the impact of clothing on the preservation of human remains is addressed in a number of articles, for example, Janaway (2001), Miller (2002), Dautartas (2009), Janaway et al. (2009), Voss et al. (2011), Humbert (2013), Phalen (2013), Teo et al. (2013), and Card et al. (2015). However, the textiles themselves and their decomposition process in association with human remains has received hardly any attention (Bouquin et al. 2013; Ueland et al. 2015).

During the 17th-19th centuries in Finland, the deceased were dressed in linen, nettle-fabric, or cotton robes that were folded, pinned, and stitched to resemble real clothing; caps and stockings crafted from bast fibers, silk, or wool; and leather gloves. Gowns and coffin-interior textiles constructed for burial were made of bits and pieces of reused fabrics; as a result, a single coffin usually contains between 7 and 20 different kinds of textiles. The deceased were either buried in the cemetery or placed beneath church floors in wooden coffins (individually or in chambers), in which they lay on top of textile mattresses and pillows stuffed with birch bark, hay, meadow plants, straw, harsh flax, or common reed (Phragmites australis), which were commonly used in mattresses in general (Tranberg 2015). Plant samples studied from Köyliö suggest that mattress materials were likely gathered from meadows and possibly stored over the winter (Lempiäinen 2016). Sometimes soft materials, such as feathers, have been found under heads of individuals, and thistledown (Circium arvense) has been found stuffed inside pillows (Lempiäinen 2016; Lipkin, Jalonen et al. 2016).

\section{Preservation of the Remains}

In normal archaeological contexts, soil is the determinative factor when it comes to preservation of the human remains and textiles, and the types of textiles that are most likely to survive. However, under Finnish church floors, in most cases, the effect of soil on preservation is limited. The interments under church floors have preserved in varying degrees, indicating that both mummification and textile preservation are complex processes and require certain circumstances that remain difficult to discern today. Adjacent coffins may have completely different preservation; one mummified individual is associated with perfectly preserved textiles, but the mummified individual in the next coffin is associated with only a few textile fragments. In addition, occasionally, skeletonized human remains in one coffin have perfectly preserved attire, while the skeletonized human remains in the adjacent coffin are brittle and decayed. Human remains interred under the church floors examined in this study are preserved in four taphonomic conditions. The benefit of these categories is that they have allowed us to identify and explore key issues facilitated by good preservation: garment identification, identification of the season of the burial, and reasons and solutions for endangered preservation. The number of burials belonging to each of these burial categories are listed in Table 1:

1. Skeletonized human remains with mostly decayed textiles.

2. Skeletonized or slightly mummified human remains with well-preserved textiles.

3. Mummified human remains (various stages) with well-preserved textiles.

4. Mummified human remains (various stages) with mostly decayed textiles.

\section{Garment Identification}

Plant-fiber funerary clothing and coffin interiors, which generally decay in most archaeological contexts, are often preserved in church under-floor contexts. Funerary clothing and coffin interiors, such as cotton or linen shirts, pillowcases, and laces, have survived in various states from clothing fragments to well-preserved funerary attire. This has naturally impacted our interpretations concerning the smallest pieces of textiles found in 
Table 1 Occurrence of preservation categories (1-4) on each site

\begin{tabular}{|c|c|c|c|c|c|c|c|}
\hline Site & Context & Preserved Textile Materials & $1^{\mathrm{a}}$ & $2^{\mathrm{b}}$ & $3^{\mathrm{c}}$ & $4^{\mathrm{d}}$ & Total \\
\hline $\begin{array}{l}\text { Oulu, } \\
\text { tuomiokirkko }\end{array}$ & Churchyard, soil contact, excavated & $\begin{array}{l}\text { Predominantly wool, silk, } \\
\text { occasionally plant fibers }\end{array}$ & 76 & - & - & - & 76 \\
\hline Oulu, Koskela & Mass burial, soil contact, excavated & $\begin{array}{l}\text { Predominantly wool, silk, } \\
\text { occasionally plant fibers }\end{array}$ & 1 & - & - & - & 1 \\
\hline Hailuoto & Under church floor, burned church, soil contact, excavated & $\begin{array}{l}\text { Predominantly wool, silk, } \\
\text { occasionally plant fibers }\end{array}$ & 24 & - & - & - & 24 \\
\hline Köyliö & Under church floor, partial soil contact, excavated & $\begin{array}{l}\text { Predominantly plant fibers, also } \\
\text { wool, silk }\end{array}$ & 5 & 1 & - & - & 6 \\
\hline Haukipudas & $\begin{array}{l}\text { Under church floor, no soil contact/occasional soil contact, } \\
\text { inventoried }\end{array}$ & $\begin{array}{l}\text { Predominantly plant fibers, also } \\
\text { silk }\end{array}$ & 1 & 6 & 3 & - & 10 \\
\hline Keminmaa & $\begin{array}{l}\text { Under church floor, no soil contact/occasional soil contact, } \\
\text { inventoried }\end{array}$ & $\begin{array}{l}\text { Predominantly plant fibers, also } \\
\text { silk }\end{array}$ & 8 & 9 & 10 & 4 & 31 \\
\hline \multirow[t]{2}{*}{ Kempele } & $\begin{array}{l}\text { Under church floor, no soil contact/occasional soil contact, } \\
\text { inventoried }\end{array}$ & $\begin{array}{l}\text { Predominantly plant fibers, also } \\
\text { silk }\end{array}$ & - & - & 8 & - & 8 \\
\hline & All & & 115 & 16 & 21 & 4 & 156 \\
\hline
\end{tabular}

\footnotetext{
${ }^{\mathrm{a}} 1=$ Skeletonized human remains with mostly decayed textiles.

${ }^{\mathrm{b}} 2=$ Skeletonized or slightly mummified human remains with well-preserved textiles.

${ }^{\mathrm{c}} 3=$ Mummified human remains (various stages) with well-preserved textiles.

${ }^{\mathrm{d}} 4=$ Mummified human remains (various stages) with mostly decayed textiles.
}

"normal archaeological contexts"; once complete garments have been identified, it is easier to recognize fragments of those garments. This has further enabled the interpretation of the burial contexts. In numerous cases, previously unidentified textile fragments have now been identified as pieces of caps, coffin furnishing, or the pleated front piece of a dress. As many clothes have turned out be gender specific, technical details that distinguish, for instance, men's and women's caps have become easily recognizable from even small textile fragments.

Among the material considered here, textiles preserved in archaeological and skeletonized contexts exhibit shrinkage at different stages, while textiles from contexts with mummified human remains display no shrinking. This is also evident at the fiber level, as the materials seem to be not remarkably shrunken and are comparable to modern reference materials. For example, the extremely fragmented textile remains from Vicar Rungius's (1560-1629) burial in Kemimaa reveal exceptionally good preservation of fibers. It is obvious that, during the decay process, many threads shrink considerably, which significantly changes the appearance of the fabric: shrinkage is usually evident at the fiber, thread, and fabric levels. However, textile decay and shrinkage are not straightforward processes. For instance, at Haukipudas, in Burial 4, apart from a wellpreserved, but inelastic and hard, silk velvet cap, the deceased's previously white plant-fiber garments are now mostly brownish, dry, brittle, and decayed into extremely small patches. However, pins have preserved pieces of the white fabric in excellent condition (Fig. 1). Additionally, bast-fiber textiles on the elderly female from Burial 4 at Köyliö are dry, brittle, and fragmentary, and by the naked eye the threads seemed to have shrunk considerably (Fig. 2). However, in microscopic examination, fibers were identified as well preserved and elastic.

In general, the thread thicknesses of dry and brittle archaeological textiles should be examined and considered with caution because preservation of individual pieces of fabric in different parts of same burial may lead to erroneous interpretations; should the threads of the same piece in different locations vary greatly in appearance due to differential preservation, they may consequently be interpreted as different fabrics rather than part of a larger whole. For this reason, particular attention should be given to the identification of different weaving structures and general appearance within textile samples.

\section{Identification of the Season of Burial}

Throughout the research, the hypothesis has been that the mummified individuals were buried during cold 

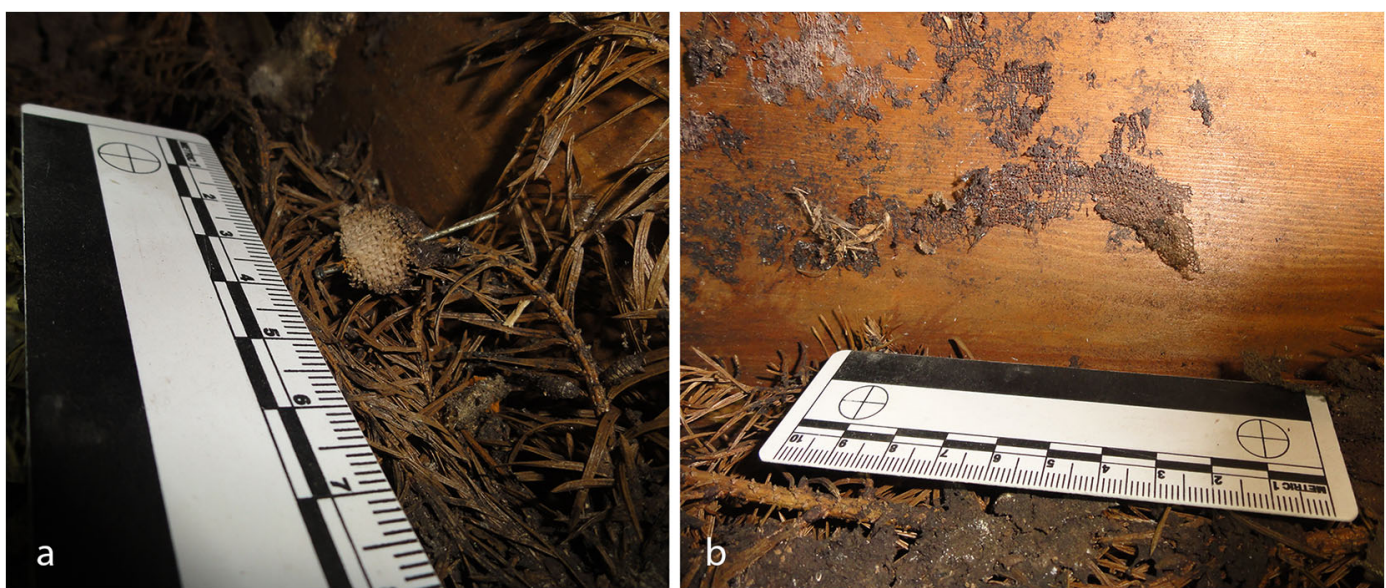

Fig. 1 The same fabric may exhibit different levels of preservation. Inside Burial 4 at Haukipudas, funerary textiles are mostly brown and brittle $(a)$, but fragments attached to the pins are white and have a close-to-original appearance (b). (Photo by S. Lipkin, 2014.)

months. However, some of the individuals with wellpreserved funerary textiles have skeletonized or have only some skin remains. This has lead us to consider the reasons for this decay process. Identification of the insect remains and observation of the textile staining are important in estimation of the burial season and its effect on putrefaction and preservation.

In the case of some church burials from Haukipudas we have information on individuals' times of death. For instance, the skeletonized human remains of a child in Burial 3 belong to a two-year-old boy who died from smallpox in July during the 1760s and was buried seven

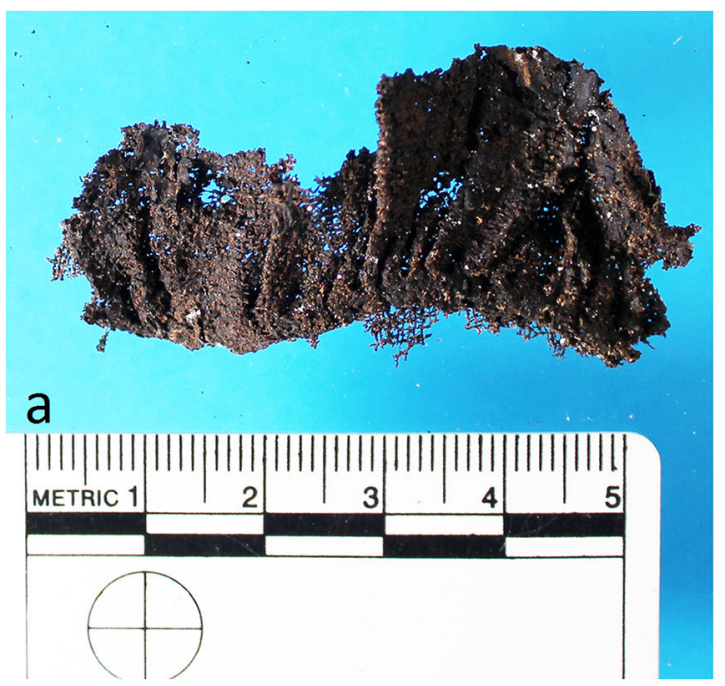

Fig. 2 Textile remains in Burial 4 at Köyliö were fragmentary and brittle, but covered about $50 \%$ of the human remains. The dress of this elderly woman had pleating in cuffs $(a)$ and a buttonhole in the days later with his name, birth date, and death date written inside the coffin with ink. Both textile staining and insect remains indicate the quick decomposition of the soft tissues during the temperate season. The fabric covering the inside wall of the coffin exhibits staining, suggesting that at some point there was liquid below the human remains. Nevertheless, the clothing and hair are extremely well preserved. The boy was buried in white funerary attire with yellow, but faded, silk sleeve cuffs (Fig. 3). The sleeves and the cuffs had been attached with copper-alloy pins. The clothes are covered with dust, and the greatest decay, discoloration, and

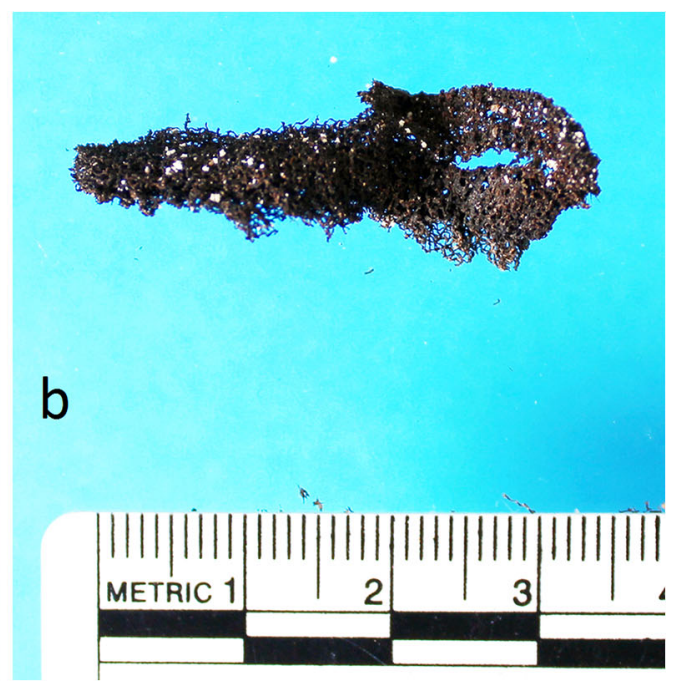

back $(b)$. Although the textile fragments are brittle and dry, they display good preservation at the fiber level. (Photo by S. Lipkin, 2015.) 
Fig. 3 Sleeve cuffs in Burial 3 at Haukipudas are decorated with yellow silk, narrow tape, and frill. All decorative elements were attached with pins. A rodent has made a hole in the coffin. The staining and chipping possibly caused by a rodent are also visible. (Photo by S. Lipkin, 2014.)

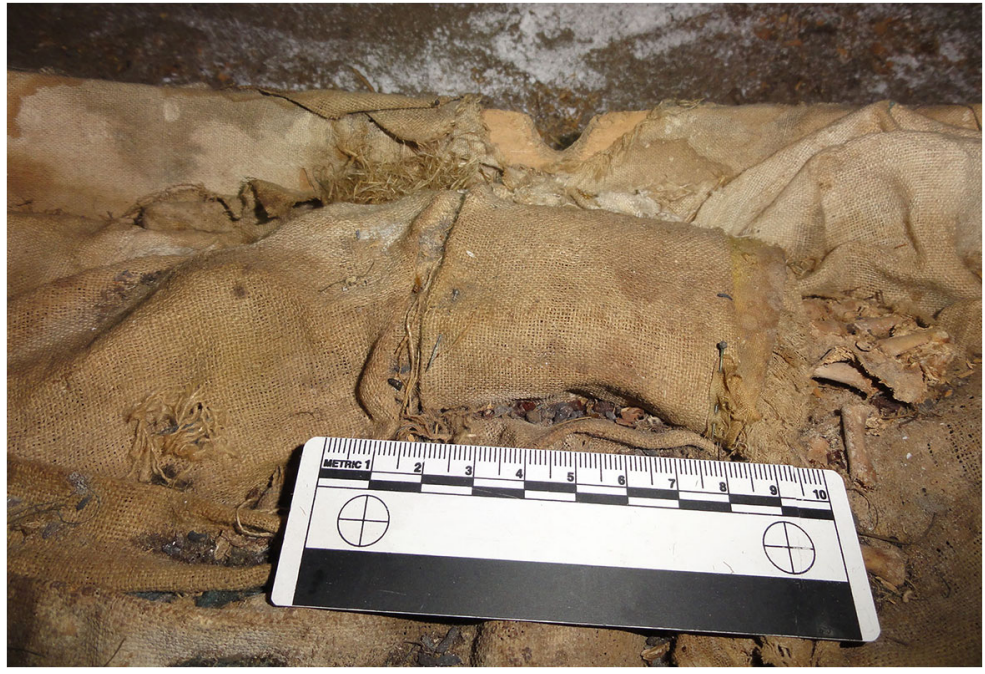

darkening of white fabrics occurred in the torso area. Blowfly cocoons (Calliphora spp.), indicating a temperate environment, were found in this same area of the human remains. Skin moth (Monopis laevigella) larvae, which thrive in cooler temperatures in low light at the end of the day, were found on the cushion under the body. These larvae feed on animal products from December to March and have been found on dry animal carcasses, in birds' nests, and in owl pellets. They have also been found to eat feathers, fur, hair, carpets, rags, and rotten fabrics (Kimber 2010; van Nieukerken and Karsholt 2013; Aarvik et al. 2017:34). Remains of skin moths were also found in Burial 1 on both the chest of the mummified human remains and the textiles. Coffins underneath church floors are an ideal habitat for skin moths, which can damage mummies and textiles even after the mummification process is finished, although their impact is then less apparent.

In some cases, it is possible to identify buried individuals based on church records and the burials' locations under the floors. Based on existing church records, the skeletonized newborn in Burial 2 in Haukipudas died from unknown causes in either March (buried three weeks after death) or May (buried one week after death) during the 1750 s or 1760 s. Identification is based on the location of the coffin beneath the church, as well as the fact that a member of the same family, with the name of the deceased written inside the coffin, was laid right next to the newborn's coffin. The various insect remains in the coffin were sampled, especially those around the head and above and below the cover fabric. Plenty of Megaselia flies - also known as the "coffin fly," as they could continue to live inside the coffin-were found around the individual's head (Fig. 4). Muscina flies, which commonly breed on manure and defecate on food, were also found. Muscina larvae can also live on dead bodies (Smith 1986; Byrd and Castner 2001:54). Protophormia terraenovae (northern blowflies), which are quickly drawn to a recently deceased corpse, were found on the cover textile. Additionally, museum beetle (Anthrenus museorum) and a few latrine-fly (Fannia scalaris) remains were found under the cover fabric. A. museorum are known to destroy organic material, such as wool, leather, fur, and silk (Robinson 2005:97). Fannia adults infest human remains that have decomposed and have reached a semiliquid state, and their maggots live inside body cavities. F. scalaris usually lays eggs on dung (Smith 1986; Byrd and Castner 2001:54). Insect species imply that the human remains had liquefied during the decomposition process, and it is likely that both human remains and textiles were immersed in liquefied soft tissue. Staining on the pillow and cover fabrics support this and suggest that, at some point, they absorbed a considerable amount of liquid. Despite these aspects of the decay process, the infant's clothes are intact and soft, similar to when they were deposited almost 300 years ago. The white funerary attire decorated with printed fabric on the bodice had only dust on it. Under microscopic analysis the fibers proved to be in good condition, though some additional material is also present. It is also possible that the newborn's remains decayed more slowly because she was buried during spring, when relatively warm days are followed by temperatures dropping below $0^{\circ} \mathrm{C}$ at 
Fig. 4 Megaselia flies, the socalled coffin fly, are found by the head of the human remains in Burial 2 in Haukipudas. (Photo by S. Lipkin, 2014.)

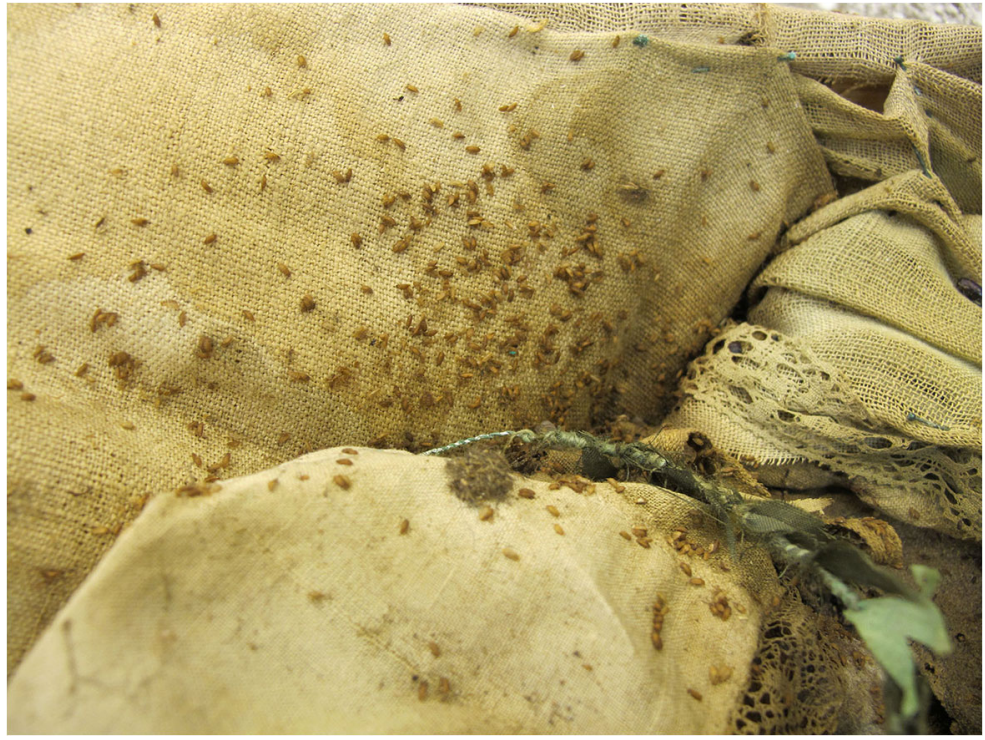

night. In addition, the use of antimicrobial mattressbedding materials, such as pinewood sawdust, may have had a positive effect on the preservation of the smaller human remains.

Some of the skeletonized adult human remains found under church floors exhibit poor textile preservation. According to the church death records and the coffin location under Haukipudas church, it is possible that the male individual in Burial 4 died from tuberculosis in November in the 1780s (Paavola 2012:108). He is buried in a pine-tar-coated coffin resting on the sandy soil under the church floor. He was lying upon a sprucebough mattress with either hay or straw in his cap, possibly from an now-decayed pillow. Inside the coffin were a number of blowfly (Calliphora spp.) remains beneath the head and shoulders. Some summer species were also identified (Lucilia spp.). The most common species found was Protophormia terraenovae (Fig. 5). The Heleomyziae spp. present were able to benefit from a drier carcass and would have appeared in the late winter and early spring (Benlow et al. 2015:73). Both the insects and brittle textile fragments suggest a quick decomposition process. If the church records and location are correct, the individual was buried 21 days after his death. In this case the individual was likely placed under the church floor during the warmer spring, summer, or fall months, and, as such, had begun the standard decomposition process prior to winter's deep freeze.

Even though some experimental case studies note that direct or close contact with soft tissue increases textile degradation, others suggest that when the clothes are immersed in bodily fluids it actually increases preservation (Ueland et al. 2015:56). The contents of decomposition fluids may also be affected by illnesses suffered by the deceased and/or medicines ingested prior to death, factors that generally cannot be identified archaeologically (Lloyd and Evans 2017). Ten out of sixteen under-floor burials with skeletonized human remains and well-preserved textiles belonged to children. In the case of burials interred during temperate months, the children's small size, in contrast with adult remains, may have contributed to the slower textile decay: that is, a smaller quantity of bodily fluids and intestinal bacteria (especially in the case of newborns) may result in better preservation of burial clothes and remains, and children's smaller bodies cool more quickly, which is crucial in terms of bacterial growth (Giles 2013:476).

Whereas insect species that eat corpses are present in burials with skeletonized human remains, the burials with mummified human remains exhibit different spectra of species. At Haukipudas, Burial 1 belongs to a mummified individual. It is likely that this girl died from fever at age seven, most likely in April in the 1760s, and was buried seven days later. The identification is based on church records and the location of the coffin beneath the floor, as well as the fact that the cover textile in this coffin was similar to the cover textile in Burial 2, who was presumably this individual's baby sister. The textiles are almost intact and nicely preserved both on the 


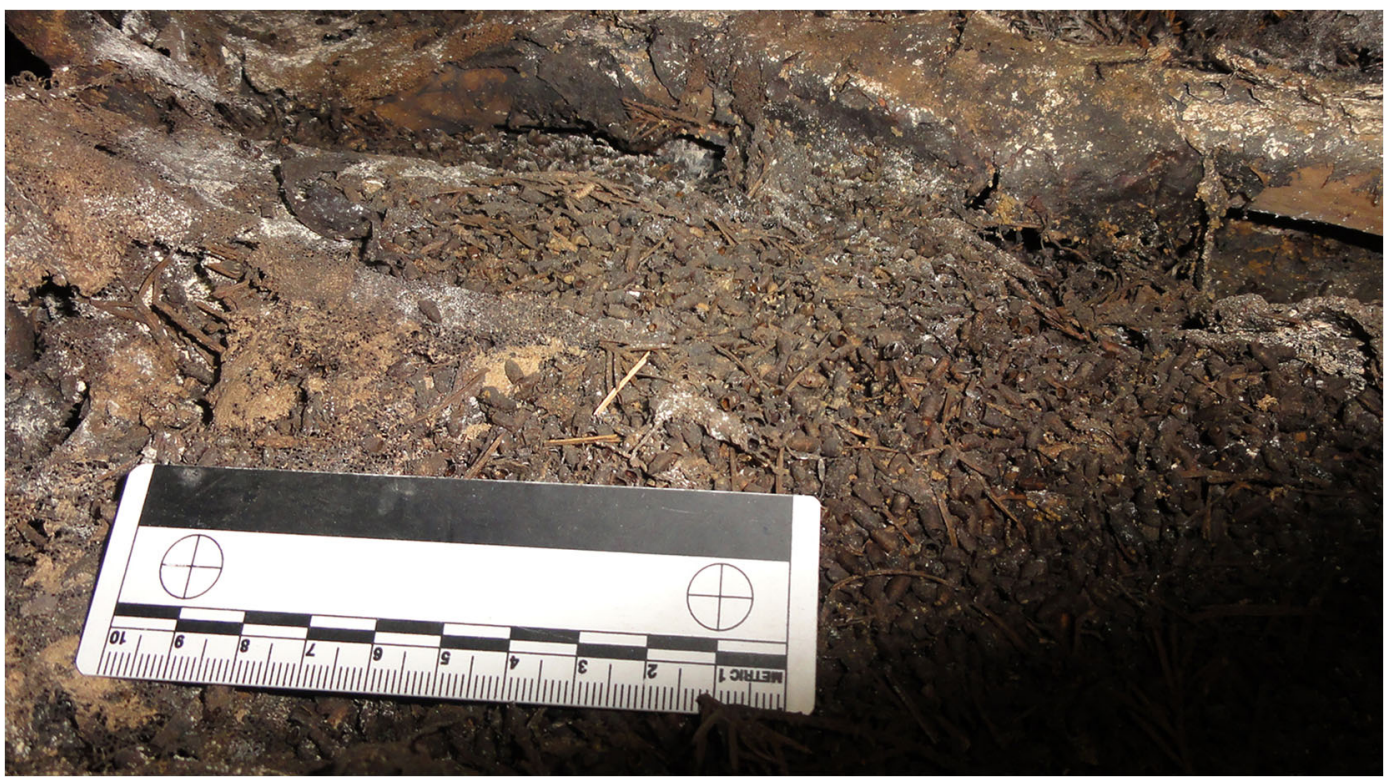

Fig. 5 Protophormia terraenovae (northern blowflies) at the stomach area in Coffin 4 at Haukipudas indicate a temperate environment. (Photo by S. Lipkin, 2014.)

macro- and fiber levels, but they are dusty and stained. However, the originally white fabrics now have a yellowish hue, and those located by the torso are brownish. The colored fabrics (now yellow and green) have lost their brightness, and the sealing wax of the coffin-edge textiles has caused reddish staining. The range of recorded insects supports an early spring interment. Hundreds of northern blowfly (Protophormia terraenovae) remains are present in this burial. The appearance of the mummy's face reflects first-instar larvae activity of northern blowflies as they consume liquid nutrition from orifices. The next instar feeds on the body itself (Goff 2000). The development from egg to adult depends on temperature, and the good condition of the mummy indicates that the first fly generation was interrupted. This interruption may have been caused by mold (not present in the burial), or cold when temperatures went below $8.95^{\circ} \mathrm{C}$. Based on the high percentage of remains still present, the constant temperature must have been between $13^{\circ} \mathrm{C}$ and $15^{\circ} \mathrm{C}$ for at least 35 days before getting cooler, although when temperatures fluctuate $P$. terraenovae reach each life stage faster than when in constant temperatures (Warren 2006). Humidity, diet quality, disease, and food availability also affect the development of this species (Logan et al. 1976).

Whereas textiles of an unidentified mummified newborn in Burial 6 at Haukipudas are well preserved, in the torso area they are brownish, similar to textiles from other child burials. This is likely due to the greater concentration of soft tissues in the torso as compared to the hands and legs. The textiles are also stained by some liquid that has dripped from the coffin lid (Fig. 6). Heleomyzidae Heleomyzini (Neoleria spp.) remains were discovered in this coffin. Male Heleomyzidae Neoleria may be found around carrion, where females oviposit on the carrion. Other heleomyzid genera gather at carrion, particularly during late winter. Heleomyzid presence indicates carrion and various kinds of decomposing organic material, both of animal and vegetable origin. Heleomyzidae larvae move during late winter and early spring, when there is still snow on ground. These larvae feed on decaying plant and animal material, mushrooms, and various fungi, and are found on dried-out carcasses (Smith 1986:82; Benlow et al. 2015:73). Heleomyzidae remains have also been found at Keminmaa in the coffins of a mummified infant in Burial 10 and a male individual in Burial 11. The male in Burial 11 most likely died in April during the 1840s. A nameplate stating the likely name of this male was found close to the coffin during the 1996 inventory, and church records indicate the death date. Despite this rather late spring interment, his remains likely mummified due to the cold, breezy air in the medieval stone church, which is cold during the day and below freezing at night. The unidentified human remains of the infant were dressed in clothing consisting of a roughly sewn, 


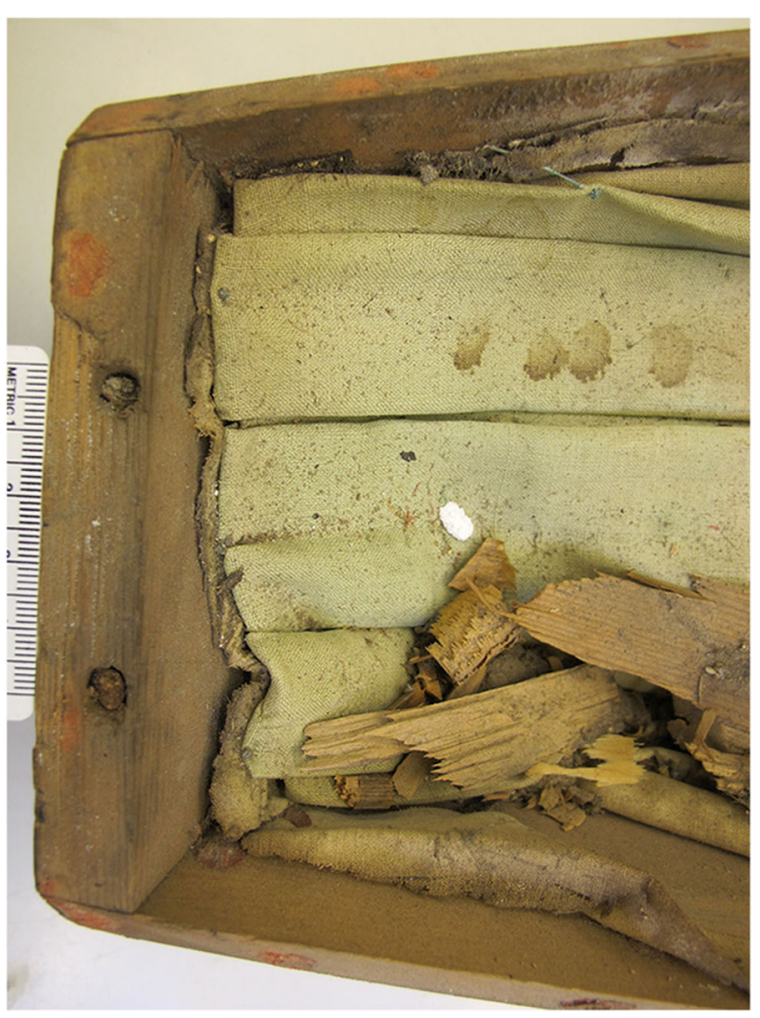

Fig. 6 Dripping liquid has stained the gown inside Burial 6 at Haukipudas. (Photo by S. Lipkin, 2014.)

light blue silk gown and undergarments, as well as a plant-fiber pillow and coffin-interior textiles that were all extremely well preserved (Lipkin, Niinimäki et al., this issue). It appears that, to provide the conditions necessary for the delayed decay process and at least partial mummification, interment between late fall (November) and early spring (March-May) was important. There are only couple of human remains that have been mummified to greater extent. One of those is Vicar Nikolaus Rungius (ca. 1560-1629) at Keminmaa, whose death date is unknown. The excellent mummification suggests that he died during the colder months, possibly late in 1629 , since his successor was consecrated in 1630 (Vahtola 1997:156-158; Väre 2017:48).

\section{Endangered Preservation}

In this study, mummified individuals with wellpreserved textiles have been found inside churches with little or no contact with soil and were likely buried during cold months (November-April). Within Finnish contexts, the cold, well-ventilated space beneath the church floors created a unique microclimate (Núñez et al. 2008:123), encouraging excellent preservation of both human remains and associated textile materials. Microorganisms are inhibited by cold, freezing conditions, and low temperatures also slow bacterial activity. Mummification was not necessarily a slow, long-term process, and experimental evidence suggests remains could mummify within a month (Bouquin et al. 2013:figure 6).

Even though most of the textiles under church floors are currently well preserved and many human remains have mummified, we cannot be confident that conditions under the floors will remain the same and that the preservation of this cultural heritage is guaranteed. Indeed, coffins, human remains, and textiles exhibit the different disruptions that have occurred over the hundreds of years of their histories. In addition to dust, a variety of extra-coffin staining and visits from both insects and rodents are represented in the coffins.

Rodents have deposited mattress materials, flax and hay/straw, on the gowns (Burial 3 at Haukipudas), and gnawed textiles (Fig. 7) and coffins. Inside the coffin of Burial 10 at Keminmaa, a rodent made its way through the textiles on the feet and also introduced a mixture of different bast-fiber filling materials from the mattress. In addition to the disturbed textiles, the rodent introduced bird cherry pits (Prunus padus, growing in the churchyard), which were found both on the deceased and inside the skull, as seen in the CT scans. The rodent visited the coffin in the time between the two inventories conducted by archaeologists from the University of Oulu in 1996 and 2013. Additionally, bank vole (Myodes glareolus) droppings were found on top of the cover textiles and at the foot of the coffin of Burial 6 at Haukipudas.

The decay of the clothes on mummified individuals may also be influenced by intentional or unintentional disturbance of graves. Interviews indicate that, in the recent past, coffins in a number of churches were opened and the remains disturbed, again affecting their preservation. In 1908, coffins at Haukipudas were opened by men, women, and children (Alakärppä and Paavola 1997:8-9). Additionally, a wooden doll was taken from one of the Haukipudas coffins in the 1970s and was later returned, presumably to a different coffin (Ojanlatva and Paavola 1997:2,21). Historical records also indicate that Vicar Rungius was moved from coffin to coffin through the centuries, likely damaging or destroying the textiles (Väre, Lipkin et al., this issue). 
Fig. 7 Textiles inside Burial 5 in Haukipudas are fragmentary. It is possible that the bank vole (Myodes glareolus) left some droppings behind or another rodent ate the fabrics. The white substance on the coffin is lime that, during the $2000 \mathrm{~s}$, the congregation of Haukipudas poured everywhere beneath the floor to keep moisture low. This is found on top of the coffins and has sometimes entered the coffins as well. (Photo by S. Lipkin, 2014.)

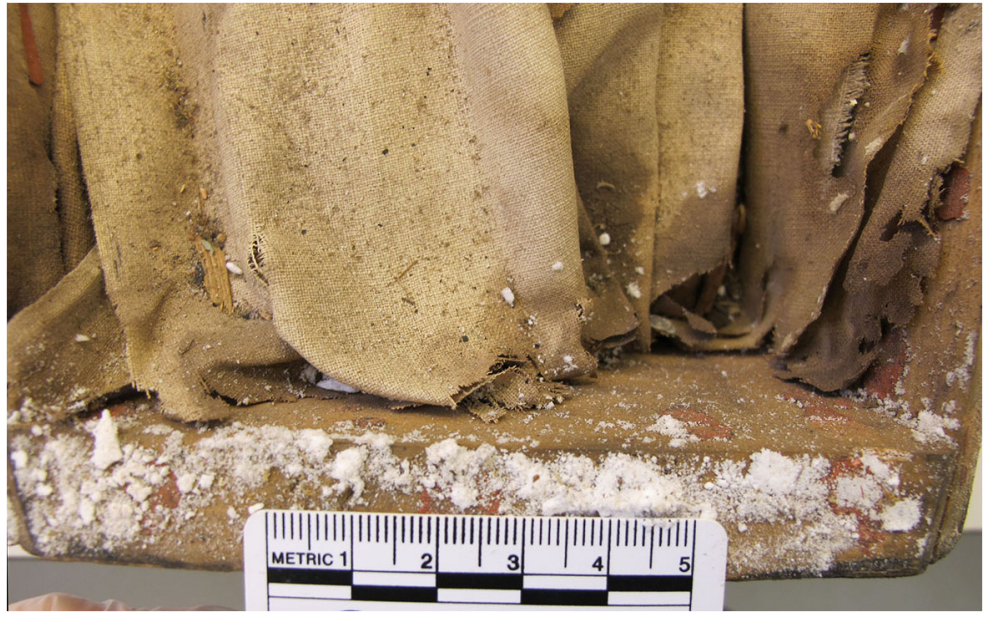

Human disturbance is also a likely explanation for the disappearance of the clothes in other burials at Keminmaa. Inside Burial 11, in addition to a wellpreserved pillowcase and a large piece of textile covering the coffin wall, only small textile fragments were found next to the feet of the mummified remains. However, right outside the coffin was a pile of textiles that may have originally been this individual's funerary attire. It remains unknown why these white garments are lying on the ground. In addition, mummified remains of a human fetus found below Keminmaa church were found without any coffin that would have protected the clothing of this individual. Close by, a fetus-sized coffin with well-preserved coffin-interior textiles was found without any human remains.

In addition to the season of the burial, the fiber material, structure, and dyestuffs of the textiles are crucial for preservation; the types of textiles themselves may favor preservation or decay. In partially mummified human remains in particular, metal salts may have played a significant role in preservation, as is seen through a comparison of the state of preservation between Burials 5 and 6 from Haukipudas; in the latter burial, the greenish tone of the textiles is possibly due to metal salts and has facilitated good preservation, whereas in Burial 5 textiles are in poorer condition. The light green tone of the textiles in Burial 6 is probably due to green paper and textile flowers that are attached to copper-alloy wreaths on the chest, arms, and head. In the places where these floral ornaments are in direct contact with textiles, the color staining is most evident (Fig. 8).
Textile preservation and decay are also dependent on the factors related to textile dyes and dye processes. Different dyeing techniques, mordant dyeing (for red) and vat dyeing (for blue), inevitably seem to effect the preservation of textiles. Vat dyeing is done in an alkaline solution, which is more harmful to wool than acidic mordant dyeing. It opens the scales present on the surfaces of wool fibers, which can facilitate bacterial attack. Madder, a source for red dye, has some preserving properties because it is antimicrobial (Torgan et al. 2016). In general, reddish wool textiles have preserved better than other textiles. Even though burials beneath church floors are not impacted by sunlight or soil, the colors in the textile materials present have still faded. Color fading may be result of changes in $\mathrm{pH}$ levels due to textile aging and bodily decay. As these fabrics were likely reused materials, it is also possible that the colors were already faded when deposited. For example, madder turns more yellow in acidic environments, while indigotin is more stable, making blue and green textiles more colorfast (Peacock 2004:192). Microbes can stain the fabrics by their activity. In some contexts in which the fiber surface is deteriorated by mold, colorants also deteriorate, which results in fading. Reuse of fabric is also evident by the recognition, through microscopic examination, of the signs of wear and washing. These are seen, for example, in hemp fibers from a "petticoat," a piece of fabric laid between the silk gown and legs in Burial 10 at Keminmaa (Fig. 9).

Even though textiles are seemingly well preserved at the fiber scale, in the case of some burials research has 
Fig. 8 The greenish staining from the textile-and-paper leaves in floral elements is the clearest where the other fabrics are attached to them. Overall, the textiles in Burial 6 at Haukipudas have a greenish tone. (Photo by $\mathrm{S}$. Lipkin, 2014.)

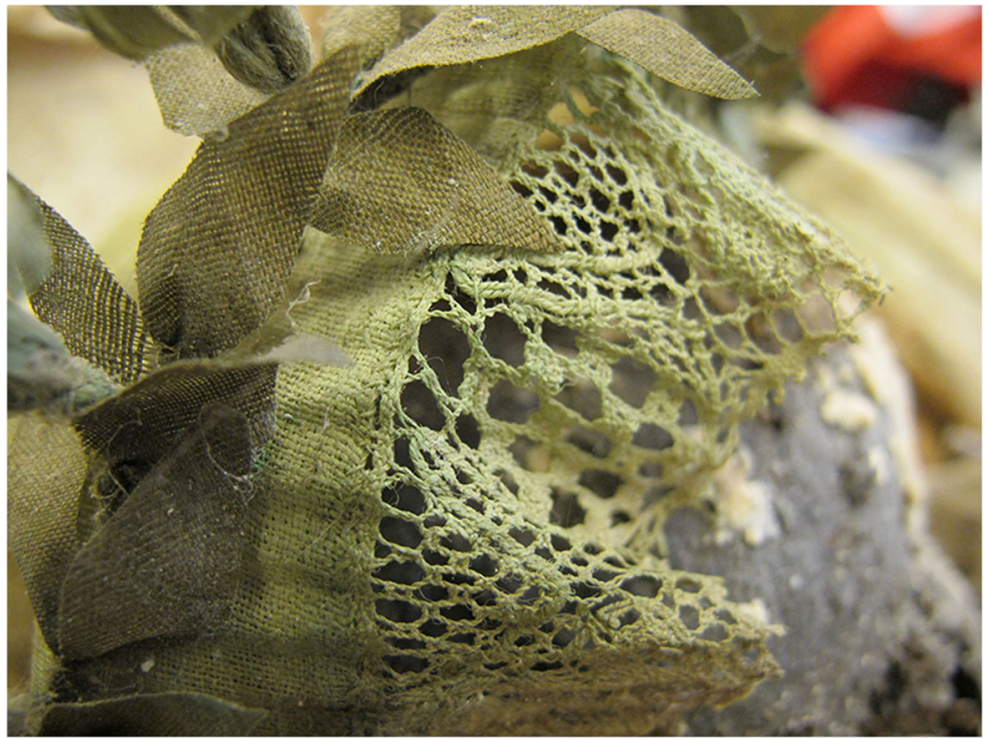

revealed that decomposition has started. For instance, in Burial 3 at Haukipudas, additional materials recorded in the fiber samples shows evidence of the start of high crystallinity decay, which means the fibers were brittle and their elasticity was lost. Additionally, the sample collected from the silk gown from Burial 10 at Keminmaa had probable salt crystals on the surface, possibly calcium chloride $(\mathrm{KCl})$. This may indicate late contamination from salt used to melt ice on local roads during the winters, or the crystals may have formed from elements in the burial itself, such as mordants or urine vat (Lipkin,
Vajanto et al. 2015:212-213). The coffin is firmly sealed, which suggests that the second option is more likely. Nevertheless, the presence of salt crystals on the surface of the fibers is harmful to their preservation. In the samples from this same burial, dormant mold spores (Fig. 10) were found. Mold has also been found in Vicar Rungius's fiber samples, and fungi grow inside some coffins in Haukipudas. These pose a possible threat for the continued preservation of these burials.

So far, growing green mold has been recorded only in Köyliö textiles. Some stomach content
Fig. 9 Signs of wear and washing are seen in a petticoat, which is evidenced by unraveling and fibrillization. The image was taken with a polarized microscope at $40 \times$ magnification. (Photo by Jenni Suomela, 2017.)

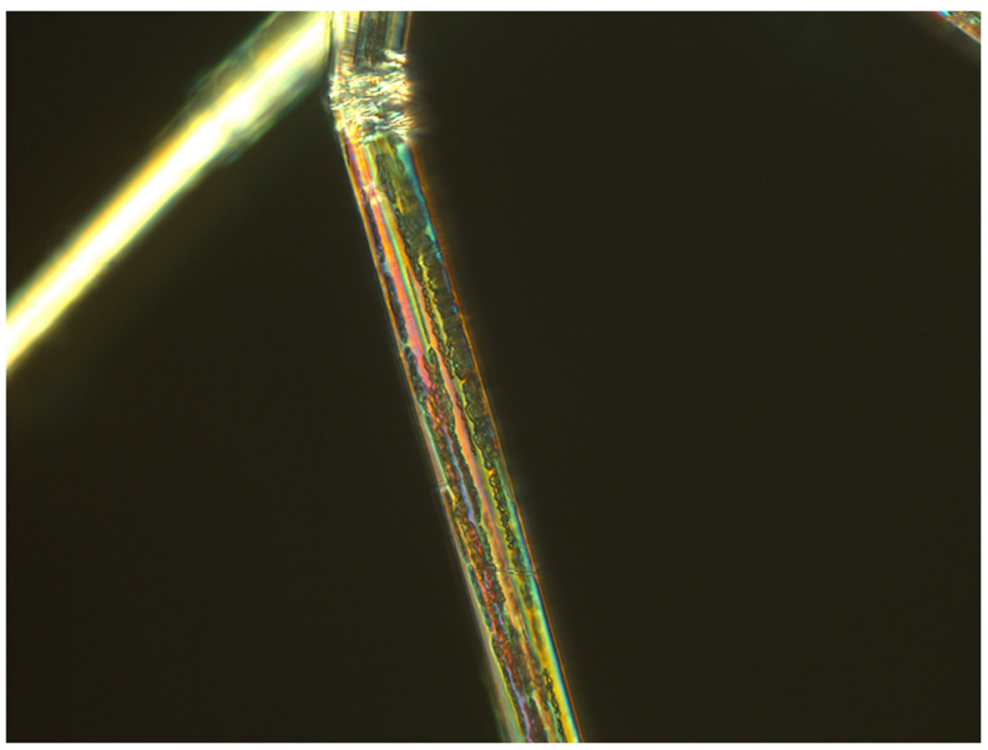


Fig. 10 Chains of ovoid spores became inactive and decayed just before they were about to germinate in a sample of a infant's silk dress from Keminmaa (Burial 10). Despite the mold, the silk fibers are well preserved. (Photo by K. Vajanto, 2014.)

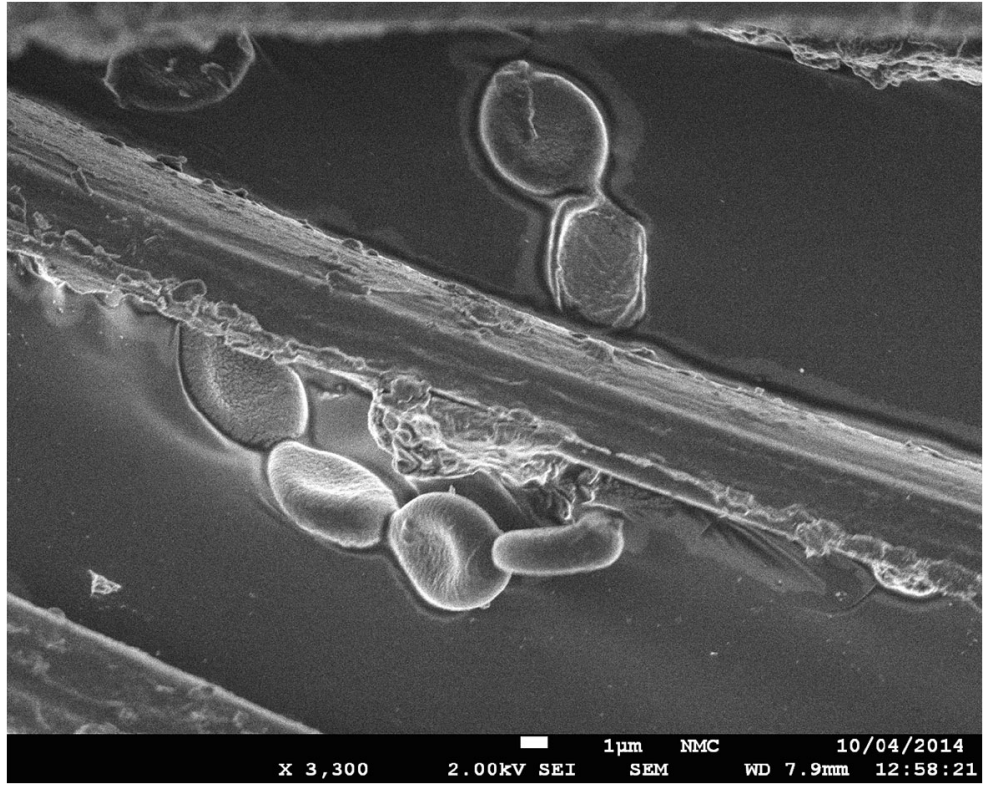

(fish bones) and human intestines were found among the preserved textiles in Burial 4 (Helamaa et al. 2016; Lempiäinen 2016; Liira 2016; Lipkin 2016). This could imply that the individual's decaying process was delayed and she was possibly partially mummified at some point. It is likely that the textiles and human remains started to decay when the coffins were covered with sand, and that soil contact initiated the molding of the Köyliö burials. Even though the coffins were not fully covered with sand, sand had penetrated the coffins. Inside the textile structures a lot of rounded inactive fungus (diameter ca. 2-3 mm), typical in any soil sample, were found. In addition, the conditions beneath the floor were suitable to activate these fungi, resulting in green mold growing on human remains and in some parts of the textiles. This evidently accelerated the decay process.

The effect of soil on under-floor church burials is especially significant for the preservation planning for the remaining mummified human remains beneath northern Finnish churches. Due to recent construction work, the conditions beneath the floors of some churches have changed and illuminated the complications of preserving this unique cultural heritage. For this reason, the Church, Space, and Memory Project has started the long-term measuring of humidity and temperature beneath church floors in Haukipudas, Kempele, and Keminmaa.

\section{Conclusions}

This article has looked for the reasons that some of the human remains in postmedieval Finland have wellpreserved clothes, while the clothes of others have decayed. While soil is the most fundamental cause for the decay of buried textiles, certain factors, such as metal artifacts and mold in the burials, as well as dyes, play a crucial part in preservation and decay processes. However, particularly noteworthy are the decay processes associated with interments beneath church floors, which hold both mummified and skeletonized human remains. We have noted that the two mummified individuals at Keminmaa (Burials 10 and 11), placed in adjacent coffins, exhibit two different kinds of preservation: while the former exhibits a nearly complete state of decay for both textiles and remains, the latter exhibits almost perfect preservation of the remains, albeit with little textile material. Additional information is required to understand clearly why such similar contexts have produced such varied results, but we believe that human disturbance is the most obvious explanation. We also have coffins of skeletonized human remains (Haukipudas Burials 2, 3, 4) that reflect completely different levels of preservation. In addition to the season of interment, in these cases preservation of the textiles may also be due to bodily liquids; adults provide more bodily liquids that contain more bacteria than do newborns and infants.

Analysis of textile staining, different modes of preservation within different parts of the corpse, and insect 
evidence immediately after death allows us to identify the season of death for each individual. In the context of this project, it was also possible to verify some death dates stated in local church records. Based on this data set, the clearest explanation for mummification and good textile preservation is interment during the winter season, which allowed for the drying of the human remains and maintained the elasticity of associated textiles. In addition, we may conclude that small infants mummify and, even if skeletonized, dry more quickly, producing better preserved funerary garments than their adult counterparts. Children's burials also include more metal objects that are favorable to textile preservation.

By classifying and documenting factors that impact both preservation and decay of archaeological textiles, identification and analysis of the textiles themselves will become easier. Understanding the taphonomic processes associated with these materials is crucial for the continued analysis, documentation, preservation, and interpretation of archaeological textile remains on a broader scale. Textile decay and preservation are not straightforward processes, but are subject to various components and environments. Over hundreds of years the environments surrounding the burials have changed, and insect and rodent, as well as human, disturbances may have been crucial in the activation of decay processes. To further study the different circumstances and factors affecting decay and preservation, controlled scientific experiments will be needed.

Acknowledgments: This article was written as part of the activities of Sanna Lipkin's Academy of Finland New Perspectives on Childhood in Finland (1600-1900): Funerary Attire as an Indicator of Status of Children Project. We would also like to thank fellow researchers from the Church, Space and Memory Project and Muuritutkimus ky for creating an encouraging and supportive working atmosphere.

Funding Open access funding provided by University of Oulu including Oulu University Hospital.

\section{Compliance with ethical standards}

Conflict of interest: On behalf of all the authors, the corresponding author states that there is no conflict of interest.

Open Access This article is licensed under a Creative Commons Attribution 4.0 International License, which permits use, sharing, adaptation, distribution and reproduction in any medium or format, as long as you give appropriate credit to the original author(s) and the source, provide a link to the Creative Commons licence, and indicate if changes were made. The images or other third party material in this article are included in the article's Creative Commons licence, unless indicated otherwise in a credit line to the material. If material is not included in the article's Creative Commons licence and your intended use is not permitted by statutory regulation or exceeds the permitted use, you will need to obtain permission directly from the copyright holder. To view a copy of this licence, visit http://creativecommons.org/licenses/by/4.0/.

\section{References}

Aarvik, Leif, Bengt Åke Bengtsson, Hallvard Elven, Povilas Ivinskis, Urmas Jürivete, Ole Karsholt, Marko Mutanen, and Nikolay Savenkov

2017 Nordic-Baltic Checklist of Lepidoptera. Thematic issue, Norwegian Journal of Entomology, Supplement No. 3. Oslo, Norway. Norsk entomologisk forening <http://www.entomolo gino/journals/nje/Suppl/Aarvik_et_al_2017_N ordic-Baltic_Checklist_of_Lepidiptera.pdf $>$. Accessed 17 September $20 \overline{2} 0$.

Alakärppä, Jalo (editor)

1997 Kempeleen Kirkkohaudat (Church burials from Kempele). Meteli, Oulun yliopiston arkeologian laboratorion tutkimusraportti 11. Oulu, Finland.

Alakärppä, Jalo, and Kirsti Paavola (editors)

1997 Haukiputaan Kirkkohaudat (Church burials from Haukipudas). Meteli, Oulun yliopiston arkeologian laboratorion tutkimusraportti 13 . Oulu, Finland.

Benlow, M. Eric, Jeffery K. Tomberlin, and Aaron M. Tarone

2015 Carrion Ecology, Evolution, and Their Applications. CRC Press, Boca Raton, FL.

Bouquin, Denis, Jean-Pol Beauthier, and Germaine Depierre

2013 The Dead Do not Dress: Contribution of Forensic Anthropology Experiments to Burial Practices Analysis. In Proceedings of the 17th International Conference on Cultural Heritage and New Technologies 2012, Wolfgang Börner and Susanne Uhlirz, editors. Museen der Stadt Wein-Stadtarchäologie, Vienna, Austria. Wein Museum-Stadt Archäologie Wien $<$ https://www.chnt.at/wp-content/uploads/eBook CHNT17 Bouxquin.pdf>. Accessed 17 September 2020 .

Byrd, Jason H., and James L. Castner

2001 Forensic Entomology: The Utility of Arthropods in Forensic Investigations. CRC Press, Boca Raton, FL.

Card, Allison, Peter Cross, Colin Moffat, and Tal Simmons

2015 The Effect of Clothing on the Rate of Decomposition and Diptera Colonization on Sus scrofa Carcasses. Journal of Forensic Sciences 60(4):979-982.

Dautartas, Angela Madeleine

2009 The Effect of Various Coverings on the Rate of Human Decomposition. Master's thesis, Department of Anthropology, University of Tennessee, Knoxville, Knoxville. 
Giles, Melanie

2013 Preserving the Body. In The Oxford Handbook of the Archaeology of Death and Burial, Sarah Tarlow and Liv Nilsson Stutz, editors, pp. 475496. Oxford University Press, Oxford, UK.

Goff, M. Lee

2000 A Fly for the Prosecution: How Insect Evidence Helps Solve Crimes. Harvard University Press, Cambridge, MA.

Janaway, Robert C.

2001 Degradation of Clothing and other Dress Materials Associated with Buried Bodies of Archaeological and Forensic Interest. In Advances in Forensic Taphonomy: Method, Theory, and Archaeological Perspectives, William D. Haglund and Marcella H. Sorg, editors, pp. 153201. CRC Press, Boca Raton, FL.

Janaway, Robert C., Andrew S. Wilson, Gerardo C. Diaz, and Sonia Guillen

2009 Taphonomic Changes to the Buried Body in Arid Environments: An Experimental Case Study in Peru. In Criminal and Environmental Soil Forensics, Karl Ritz, Lorna Dawson, and David Miller, editors, pp. 341-356. Springer, Berlin, Germany.

Helamaa, Maija, Sanni Salonen, and Oona Jalonen

2016 Köyliö, Köyliön kirkko. Kirkon lattian alaisten hautojen arkeologinen tutkimus 16.6.-9.7.2015 (Köyliö, Köyliö church. Archaeological excavation of under-floor church burials 16.6.-9.7.2015). Manuscript, Muuritutkimus ky, Kaarina, Finland.

Humbert, Lorraine L.

2013 A Preliminary Study for Estimating Postmortem Interval of Fabric Degradation in Central Florida. Bachelor's honors thesis, Department of Anthropology, University of Central Florida, Orlando.

Kehusmaa, Aimo

1997 Oulun tuomiokirkon kaivaukset 1996. Kaivauskertomus (Excavations at Oulu Cathedral 1996. Excavation report). Manuscript, PohjoisPohjanmaan museo, Oulu, Finland.

Kimber, Ian

201012.036 BF227 Skin Moth Monopis laevigella. UKMoths <https://www.ukmoths.org.uk/species/ monopis-laevigella>. Accessed 17 September 2020.

Lempiäinen, Terttu

2016 Makrofossiilianalyysi (Macrofossil analysis). In Köyliö, Köyliön kirkko Kirkon lattian alaisten hautojen arkeologinen tutkimus 16.6.-9.7.2015, Maija Helamaa, Sanni Salonen, and Oona Jalonen, authors, Appendix 7. Manuscript, Muuritutkimus ky, Kaarina, Finland.

Liira, Anne-Mari

2016 Osteologinen analyysi (Osteological analysis). In Köyliö, Köyliön kirkko Kirkon lattian alaisten hautojen arkeologinen tutkimus 16.6.-9.7.2015, Maija Helamaa, Sanni Salonen, and Oona Jalonen, authors, Appendix 8. Manuscript, Muuritutkimus ky, Kaarina, Finland.
Lipkin, Sanna

2016 Tekstiilianalyysi (Textile analysis). In Köyliö, Köyliön kirkko Kirkon lattian alaisten hautojen arkeologinen tutkimus 16.6.-9.7.2015, Maija Helamaa, Sanni Salonen, and Oona Jalonen, authors, Appendix 6. Manuscript, Muuritutkimus ky, Kaarina, Finland.

Lipkin, Sanna

2018 Tekstiiliraportti Pohjois-Pohjanmaan Museon Koskelan Sotilashautalöydöstä (Textile report at the Northern Ostrobothnia Museum on the Koskela soldiers' burial). Manuscript, PohjoisPohjanmaan museo, Oulu, Finland.

Lipkin, Sanna, Oona Jalonen, Maija Helamaa, Anne-Mari Liira, Terttu Lempiäinen, Elzbieta Djupsjöbacka, Sanni Salomaa, and Kari Uotila

2016 Burying Parishioners at Köyliö, Finland - Aspects on Attire and Burial Habits. Poster presented at European Anthropological Association annual meeting, Vilnius, Lithuania.

Lipkin, Sanna, Krista Vajanto, Titta Kallio-Seppä, Tiina Kuokkanen, Sirpa Niinimäki, Tiina Väre, and Martin van Bommel

2015 Funeral Dress and Textiles in 17th- and 19thCentury Burials in Ostrobothnia, Finland. In Aspects of the Design, Production and Use of Textiles and Clothing from the Bronze Age to the Early Modern Era. NESAT XII. The North European Symposium of Archaeological Textiles 21st-24th May 2014 in Hallstatt, Austria, Karin Grömer and Frances Pritchard, editors, pp. 209221. Archaeolingua, Budapest, Hungary.

Lloyd, Richard, and Julie Evans

2017 Forensic Toxicology of Decomposed Human Remains. In Taphonomy of Human Remains: Forensic Analysis of the Dead and the Depositional Environment, Eline M. J. Schotsmans, Nicholas Márquez-Grant, and Shari L. Forbes, editors, pp. 297-317. Wiley-Blackwell, Oxford, UK.

Logan, Jesse A., David J. Wollkind, S. C. Hoyt, and Lynell K. Tanigoshi

1976 An Analytic Model for Description of Temperature Dependent Rate Phenomena in Arthropods. Environmental Entomology 5(6):1133-1140.

Miller, Robyn A.

2002 The Affects of Clothing on Human Decomposition: Implications for Estimating Time Since Death. Master's thesis, Department of Anthropology, University of TennesseeKnoxville, Knoxville.

Núñez, Milton, Kirsti Paavola, and Elena García-Guixe

2008 Mummies in Northern Finland. In Mummies and Science, World Mummies Research, Proceedings of the VI World Congress on Mummy Studies. Teguise, Lanzarote, February 20th to 24th, 2007, Atoche Peña, C. Rodgues Martin, and M. Ángeles Ramírez Rodríquez, editors, pp. 123-128. Academia Canaria de la Historia, Santa Cruz de Tenerife, Spain. 
Ojanlatva, Eija, and Kirsti Paavola (editors)

1997 Keminmaan Kirkkohaudat (Church burials from Kemimaa). Meteli, Oulun yliopiston arkeologian laboratorion tutkimusraportti 14. Oulu, Finland.

Paavola, Kirsti

1998 Kepeät mullat. Kirjallisiin ja Esineellisiin Lähteisiin Perustuva Tutkimus PohjoisPohjanmaan Rannikon Kirkkohaudoista (Light soils. A study of church burials on the coast of northern Ostrobothnia based on written and material sources). Acta Universitatis Ouluensis B Humaniora 28. Oulu, Finland.

Paavola, Kirsti

2012 Haukiputaan kirkkohautojen ongelmalähteet (Problems of church burials from Haukipudas). In Stones, Bones and Thoughts. Festschrift in Honour of Milton Núnez, Sirpa Niinimäki, AnnaKaisa Salmi, Jari-Matti Kuusela, and Jari Okkonen, editors, pp. 101-111. University of Oulu, Oulu, Finland.

Peacock, Elizabeth E.

2004 Moseforsøg-Two Generations of Bog Burial Studies. Interim Textile Results. In Priceless Invention of Humanity. NESAT VIII. Report from the 8th North European Symposium for Archaeological Textiles, 8-10 May 2002 in Łódź, Poland, Jerzy Maik, editor, pp. 185-193. Łódzkie Towarzystwo Naukowe, Lodz, Poland.

Phalen, Kathryn A.

2013 Assessing the Effects of Clothing on Human Decomposition Rates in Central Texas. Master's thesis, Department of Anthropology, Texas State University, San Marcos.

Robinson, William $\mathrm{H}$.

2005 Handbook of Urban Insects and Arachnids. Cambridge University Press, Cambridge, UK.

Sarkkinen, Mika, and Aimo Kehusmaa

2002 Oulun tuomiokirkon kirkkotarhasta (About Oulu Cathedral Cemetery). Manuscript, Oulun ev. lut. seurakuntayhtymä and Museoviraston rakennushistorian osasto, Oulu, Finland.

Smith, Kenneth G. V.

1986 A Manual of Forensic Entomology. Cornell University Press, Ithaca, NY.

Teo, Chee Hau, Amir Pawita, Osman Khairul, Abdul G. Atiah Ayunni, and Hamzah Noor Hazfalinda

2013 Post Mortem Changes in Relation to Different Types of Clothing. Malaysian Journal of Pathology 35(1):77-85.

Torgan, Emine, Rezan Alkan, and Recep Karadag

2016 Antifungal Activity and HPLC Analyses of Silk Fabrics Dyed with Madder and Gallnut. Poster presented at the Dyes in History and Archaeology conference, Pisa, Italy.

Tranberg, Annemari

2015 Burial Customs in the Northern Ostrobothnian Region (Finland) from the Late Medieval Period to the 20th Century. Plant Remains in Graves. In The Archaeology of Death in Post-Medieval Europe, Sarah Tarlow, editor, pp. 189-203. De Gruyter Open, Warsaw, Poland.

Ueland, Maiken, Katie D. Nizio, Shari L. Forbes, and Barbara H. Stuar

2015 The Interactive Effect of the Degradation of Cotton Clothing and Decomposition Fluid Production Associated with Decaying Remains. Forensic Science International 255:56-63.

Vahtola, Jouko

1997 Vaikea vuosisata (1601-1721) (Difficult century [1601-1721]). In Keminmaan Historia, Pentti Koivunen, Jouko Vahtola, Reija Satokangas, and Martti Itkonen, editors, pp. 86-177. Keminmaan kunta, Keminmaa, Finland.

van Nieukerken, Erik J., and Ole Karsholt

2013 Monopis laevigella. Fauna Europaea <https://fauna -eu.org/cdm_dataportal/taxon/60220cd7-5483-4f2f -924b-7b918490cab0>. Accessed 17 September 2020.

Väre, Tiina

2017 Osteobiography of Vicar Rungius: Analyses of the Bones and Tissues of the Mummy of an Early 17thCentury Northern Finnish Clergyman Using Radiology and Stable Isotopes. Acta Universitatis Ouluensis B Humaniora 150. Oulu, Finland. Jultika: University of Oulu Repository <http://urn .fi/urn:isbn:9789526215259>. Accessed 25 August 2020.

Voss, Sasha C., David F. Cook, and Ian R. Dadour

2011 Decomposition and Insect Succession of Clothed and Unclothed Carcasses in Western Australia. Forensic Science International 211(1-3):67-75.

Warren, Jodie-Ann

2006 The Development of Protophormia Terraenovae (Robineau-Desvoidy) (Diptera: Calliphoridae) at Constant and Fluctuating Temperatures. Master's thesis, School of Criminology, Simon Fraser University, Burnaby, BC.

Publisher's Note Springer Nature remains neutral with regard to jurisdictional claims in published maps and institutional affiliations. 